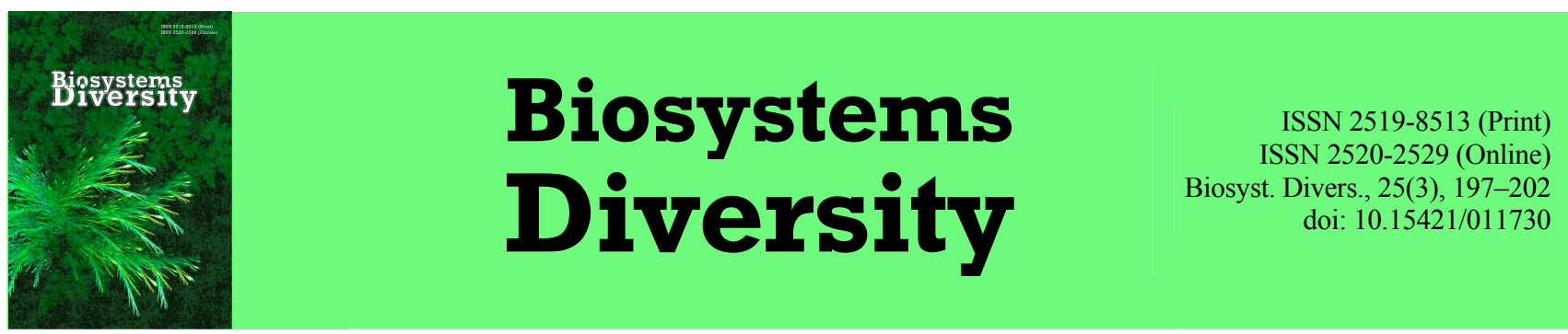

\title{
Seasonal dynamics of the littoral zooplankton groups of the Uday River within the National Nature Park "Pyryatynsky"
}

\author{
Z. V. Burian, V. M. Trokhymets, V. P. Gandzyura \\ Taras Shevchenko Kyiv National University, Kyiv, Ukraine
}

Article info

Received 10.07.2017

Received in revised form 15.08.2017

Accepted 16.08.2017

Taras Shevchenko Kyiv National University, Volodymyrska Str., 64 Kyiv, 03022, Ukraine. Tel.: +38-097-679-17-94. E-mail:

ke7sha1991@gmail.com
Burian, Z. V., Trokhymets, V. M., \& Gandzyura, V. P. (2017). Seasonal dynamics of the littoral zooplankton groups of the Uday River within the National Nature Park "Pyryatynsky". Biosystems Diversity, 25(3), 197-202. doi:10.15421/011730

The increase in anthropogenic impact on aquatic ecosystems causes significant alterations in the composition and structure of hydrobiont groups. These processes are characteristic of the hydrobiocenoses of the Uday River, the valley of which lies within the National Nature Park "Pyryatynsky", established in 2009 in the Pyryatyn district of Poltava region. Within this protected area it is convenient to carry out continuous monitoring of changes in anthropogenic load on shore ecosystems of the river. One of the most convenient monitoring groups is zooplankton, which is one of the essential components of the trophic networks of aquatic ecosystems and which is the feeding basis of planktonophagous and young fish. The object of this research was the major groups of zooplankton: rotifers (class Eurotatoria), cladocerans (class Branchiopoda, order Cladocera), different age stages of copepods (class Copepoda), ostracods (class Ostracoda). Zooplankton were collected in the daytime in spring (mid April), summer (end of July) and autumn (late September) 2016 within eight research stations. As a result of the conducted research, 69 species of zooplankton were registered within the littoral water area of the Uday River. Monogonont rotifers numbered $19(27.5 \%)$ species, bdelloid rotifers (subclass Bdelloidea), cladocerans - 33 (47.9\%) species, copepods - 17 (24.6\%). According to the faunal spectrum in the zooplankton groups, representatives of the cladoceran complex predominated. This is due to the favourable conditions for the development of filtrators, of which a considerable part is cladocerans. Three species of rotifers were identified in Poltava region for the first time: Beauchampiella eudactylota (Gosse, 1886), Dipleuchlanis propatula (Gosse, 1886), Mytilina acanthophora (Hauer, 1938). During the spring, 33 species of zooplankton were collected: rotifers - 10 species, cladocerans 14 , copepods -9 species. In summer 41 species were registered, including rotifers -10 , cladocerans -18 , and copepods -13 . In autumn 37 species were found: 6 species of rotifers, cladocerans -21 and copepods -10 . The species composition of the zooplankton in different seasons had a low similarity, as evidenced by Jaccard index: spring and autumn $(J=25,4)$, spring and autumn $(\mathrm{J}=34,5)$, and summer and autumn $(\mathrm{J}=34,6)$. In the spring, pelagic $(36.3 \%)$ and phytophilic $(45.6 \%)$ groups prevailed, and phytophilic dominated in summer $(41.4 \%)$ and autumn $(48.7 \%)$. Of the various groups classified according to feeding type, representatives of the peaceful group dominated in all the studied seasons, in spring comprising $69.7 \%$, in summer $-65.8 \%$, and in autumn $-73 \%$. The density and biomass of zooplankton of the Uday River were "low" in spring and summer, and "very low" - in autumn.

Keywords: zooplankton; seasonal dynamics; Uday River; Ukraine

\section{Сезонна динаміка угруповань прибережного зоопланктону річки Удай у межах Національного природного парку «Пирятинський»}

\author{
3. В. Бур'ян, В. М. Трохимець, В. П. Гандзюра
}

\section{Київський національний університет імені Тараса Шевченка, Київ, Украӥна}

Наведено результати аналізу сезонної динаміки угруповань зоопланктону річки Удай в межах Національного природного парку «Пирятинський» за 2016 рік. Видове багатство у межах восьми дослідних станцій представлене 69 видами моногононтних коловерток, гіллястовусих і веслоногих ракоподібних. Уперше для Полтавської області визначено три види коловерток: Beauchampiella eudactylota (Gosse, 1886), Dipleuchlanis propatula (Gosse, 1886), Mytilina acanthophora Hauer, 1938. Максимальне видове багатство (41 вид) зареєстровано влітку, що пов'язано з бурхливим розвитком макрофітів (і оптимальною для них температурою). Протягом трьох сезонів за фауністичним спектром в угрупованнях зоопланктону переважали представники кладоцерного комплексу. Виявлено невисокі значення індексу видової схожості Жаккара для різносезонних угруповань зоопланктону: J = 25,4-34,6. Проаналізовано сезонні зміни основних екологічних показників угруповань зоопланктону: екологічний спектр, тип живлення, щільність, біомаса. В угрупованнях зоопланктону протягом року відбулася зміна домінантної пелагічної групи на фітофільну. Для таких водойм, як річка Удай, класичним виявився трофічний спектр угруповань зоопланктону, представлений трьома групами, значний відсоток 3 яких склали мирні представники: весна $69,7 \%$, літо - 65,8\%, осінь - 73,0\%. Навесні в межах зарослого біотопу та на чистоводді відмічено найвищі показники щільності та біомаси.

Ключові слова: зоопланктон; сезонна динаміка; річка Удай; Україна 


\section{Вступ}

На території більшості країн світу не залишилось річок, які не зазнали б господарської діяльності (Baranyi et al., 2002; Illyová et al., 2008; Czerniawski and Domagała, 2010; Burdis and Hoxmeier, 2011; Fefilova, 2011; Czerniawski et al., 2013). Територія України вкрита мережею річок, більшість яких належить до басейнів Чорного, Азовського морів. Водні ресурси малих річок мають істотне значення для людини та підтримки екологічної рівноваги в регіоні. 3 року в рік в Україні збільшується кількість річок із докорінно зміненим режимом (Smyrnova, 2013). Саме малі річки найвразливіші відносно антропогенного впливу (Yatsyk et al., 1991). Внаслідок проведення недосконалої водної меліорації, високої розораності земель, розорювання прибережних захисних смуг і заплав, випрямлення русел річок спостерігається розрегульованість їх стоку, прогресуюче обміління, замулювання та зникнення (Smyrnova, 2013). Унаслідок перебудови водних екосистем відбуваються якісні та кількісні зміни угруповань гідробіонтів (Segers, 2008; Kononova, 2009; Uttah et al., 2010; Czerniawski and Pilecka-Rapacz, 2011; Podshivalina, 2012; Napiórkowski and Napiórkowska, 2013; Ning et al., 2013; Pashkova, 2013; Yermolaeva, 2013). Особливу увагу привертає річка Удай, долина якої розташована в межах Національного природного парку «Пирятинський» Пирятинського району Полтавської області, створеного у 2009 році. Оскільки парк нещодавно створений, на його території можна прослідкувати зміну антропогенного навантаження на водойму.

Зоопланктон - важливий компонент трофічних ланцюгів водних екосистем і основа кормової бази риб-планктофагів і молоді риб. Дослідження структурно-функціональної організації угруповань зоопланктону річки Удай НПП «Пирятиський» розпочали в 2010 році (Trokhymets et al., 2011). У статті наведено результати дослідження сезонних змін угруповань зоопланктону річки Удай в межах Національного природного парку «Пирятинський».

\section{Матеріал і методи досліджень}

Об’єкт досліджень - основні групи зоопланктону: коловертки (клас Eurotatoria), гіллястовусі ракоподібні (клас Branchiopoda, ряд Cladocera), різні вікові стадії розвитку веслоногих ракоподібних (клас Copepoda), черепашкові ракоподібні (клас Ostracoda). Моногононтних коловерток, гіллястовусих і веслоногих ракоподібних визначали до виду, а бделоїдних коловерток (підклас Bdelloidea) та черепашкових ракоподібних - до вищих таксономічних груп надвидового рангу. Матеріалом дослідження послужив зоопланктон, зібраний у світлу пору доби навесні (15 квітня), влітку (2025 липня) і восени (26 вересня) 2016 року у межах восьми дослідних станцій річки Удай (рис. 1): околиці селищ Кроти N 50²3.196' Е 32²8.497', Гурбинці N 50²1.816' Е 32²8.610', Леляки N 50²0.140' Е 32²9.705', Кейбалівка N 50¹8.352' Е $32^{\circ} 30.095$ ', Велика Круча N 50¹1.167’ Е 32³4.325', Повстин $\mathrm{N} 50^{\circ} 11.183^{\prime}$ Е $32^{\circ} 40.283^{\prime}$ та м. Пирятин - Сумський міст N 50¹3.636' Е 32³3.324', острів Масальський N 50¹4.344' E $32^{\circ} 31.831$ '. Досліджували зоопланктон у межах різних біотопів: зарослого - у формаціях очерету звичайного, рогозу широколистого, глечиків жовтих, латаття біолого, тілоріза звичайного, частухи подорожникової, ряски малої, стрілолиста звичайного та на чистоводді. Збирали зоопланктон шляхом фільтрації через конічну планктонну сітку. Всього зібрали та проаналізували 46 проб зоопланктону на основі загальноприйнятих методик (Zhadin, 1960; Маnujlova, 1964; Pesenko, 1982; Berezina, 1989; Martin and Davis, 2001; Monchenko, 2003; Arsan et al., 2006; Segers, 2007; Ovander et al., 2011).

\section{Результати}

Протягом року дослідження річки Удай в межах Національного природного парку «Пирятинський» зареєстровано 69 видів зоопланктону. Моногононтні коловертки нараховували 19 (27,5\%) видів і бделоїдних коловерток, гіллястовусі ракоподібні - 33 (47,9\%), веслоногі ракоподібні - 17 (24,6\%) видів (табл. 1). За фау- ністичним спектром в угрупованнях переважали представники кладоцерного комплексу, на частку яких припадала майже половина видового багатства прибережного зоопланктону.

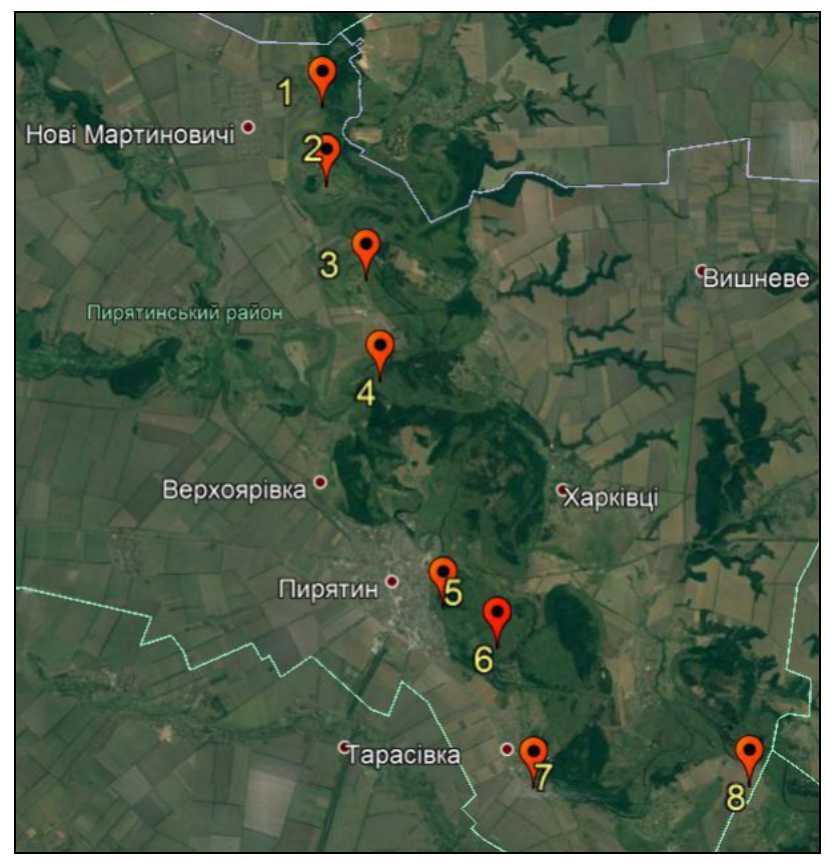

Рис. 1. Станції відбору проб зоопланктону річки Удай у межах НПП «Пирятинський»: околиці селищ 1 - Кроти, 2 - Гурбинці, 3 - Леляки, 4 - Кейбалівка, 7 - Велика Круча, 8 - Повстин, 5 -

Сумський міст, м. Пирятин, 6 - острів Масальський

Вперше для Полтавської області визначено три види коловерток: Beauchampiella eudactylota (Gosse, 1886), Dipleuchlanis propatula (Gosse, 1886), Mytilina acanthophora Hauer, 1938.

\section{Таблиця 1}

Видовий склад зоопланктону річки Удай у межах НПП «Пирятинський»

\begin{tabular}{|c|c|c|c|c|}
\hline \multirow{2}{*}{ № } & \multirow{2}{*}{ Види } & Весна & Літо & Осінь \\
\hline & & \multicolumn{3}{|c|}{$\mathrm{P}, \%$} \\
\hline \multicolumn{5}{|c|}{ Клас Eurotatoria } \\
\hline 1 & Asplanchna priodonta Gosse, 1850 & 12,5 & 37,5 & - \\
\hline & Beauchampiella eudactylota (Gosse, 1886) & - & 37,5 & - \\
\hline 3 & Brachionus calyciflorus Pallas, 1766 & 12,5 & - & - \\
\hline & B. nilsoni Ahlstrom, 1940 & 25,0 & - & - \\
\hline & B. quadridentatus Hermann, 1783 & - & 37,5 & - \\
\hline & B. urceolaris O.F.Müller, 1773 & - & - & 37,5 \\
\hline & Conochilus hippocrepis (Schrank, 1803) & 12,5 & - & - \\
\hline & Dipleuchlanis propatula (Gosse, 1886) & - & 25,0 & - \\
\hline & Euchlanis deflexa (Gosse, 1851) & 12,5 & - & 12,5 \\
\hline & Eu. dilatata Ehrenberg, 1832 & 25,0 & - & 50,0 \\
\hline 11 & Eu. pyriformis Gosse, 1851 & 12,5 & - & - \\
\hline 12 & Lecane bulla (Gosse, 1851) & - & 25,0 & - \\
\hline 13 & L. luna (O.F.Müller, 1776) & - & 25,0 & 12,5 \\
\hline 14 & L. lunaris (Ehrenberg, 1832) & - & 25,0 & - \\
\hline 15 & Mytilina acanthophora Hauer, 1938 & - & 12,5 & - \\
\hline 16 & Notholca acuminata (Ehrenberg, 1832) & 87,5 & - & - \\
\hline 17 & Platyias quadricornis (Ehrenberg, 1832) & - & 100,0 & 25,0 \\
\hline & Testudinella patina (Hermann, 1783) & 12,5 & 100,0 & 12,5 \\
\hline & Trichotria pocillum (O. F. Müller, 1776) & 25,0 & - & - \\
\hline & Bdelloidea Hudson, 1884 & 37,5 & 87,5 & 50,0 \\
\hline & $S$ видів коловерток & 10 & 10 & 6 \\
\hline \multicolumn{5}{|c|}{ Клас Branchiopoda, ряд Cladocera } \\
\hline 20 & Acroperus harpae (Baird 1834) & 37,5 & - & 12,5 \\
\hline 21 & Alona affinis (Leydig, 1860) & - & 25,0 & - \\
\hline 22 & A. rectangula Sars, 1862 & 12,5 & 12,5 & 25 \\
\hline 23 & Alonella excisa (Fischer, 1854) & 25,0 & - & - \\
\hline 24 & A. nana (Baird 1843) & 12,5 & 12,5 & 12,5 \\
\hline 25 & Alonopsis ambigua Lilljeborg, 1900 & - & 12,5 & - \\
\hline 26 & Bunops sericaudata Daday, 1885 & - & 87,5 & - \\
\hline 27 & Bosmina longirostris (O.F.Müller, 1776) & 12,5 & 12,5 & - \\
\hline
\end{tabular}




\begin{tabular}{|c|c|c|c|}
\hline \multirow{2}{*}{ Види } & Весна & Літо & Осінь \\
\hline & \multicolumn{3}{|c|}{$\mathrm{P}, \%$} \\
\hline 28 Camptocercus rectirostris Schoedler, 1862 & - & - & 37,5 \\
\hline 29 Ceriodaphnia affinis Lilljeborg, 1900 & 12,5 & 100,0 & 37,5 \\
\hline 30 C. laticaudata P.E.Müller, 1867 & - & 12,5 & - \\
\hline 31 C. megalops Sars, 1862 & - & 12,5 & - \\
\hline 32 C. pulchella Sars, 1862 & - & 50,0 & 12,5 \\
\hline 33 C. reticulata (Jurine, 1820) & - & - & 12,5 \\
\hline 34 C. quadrangula (O.F.Müller, 1785) & - & 12,5 & 25,0 \\
\hline 35 Chydorus latus Sars, 1862 & 12,5 & - & - \\
\hline 36 Ch. piger Sars, 1862 & 100,0 & 25,0 & 25,0 \\
\hline 37 Ch. sphaericus (O.F.Müller, 1785) & 37,5 & - & 12,5 \\
\hline 38 Daphnia cucullata Sars, 1862 & - & - & 12,5 \\
\hline 39 D. pulex Leydig, 1860 & 25,0 & 37,5 & 25,0 \\
\hline 40 Diaphanosoma brachyurum (Lievin, 1848) & - & 25,0 & - \\
\hline 41 Disparalona rostrata $($ Koch, 1841$)$ & - & 12,5 & - \\
\hline 42 Eurycercus lamellatus (O.F.Müller, 1776) & - & 12,5 & 12,5 \\
\hline 43 Graptoleberis testudinaria (Fischer, 1848) & 25,0 & - & 12,5 \\
\hline 44 Ilyocryptus agilis Kurz, 1878 & - & - & 25,0 \\
\hline 45 I. sordidus (Lievin, 1848) & _- & 12,5 & - \\
\hline 46 Oxyurella tenuicaudis (Sars, 1862) & - & - & 12,5 \\
\hline 47 Picripleuroxus laevis Sars, 1862 & - & - & 25,0 \\
\hline 48 P. striatus Schödler, 1862 & - & - & 12,5 \\
\hline 49 Pleuroxus aduncus (Jurine, 1820) & 62,5 & - & 37,5 \\
\hline 50 Scapholeberis echinulata Sars, 1903 & 12,5 & - & - \\
\hline 51 S. mucronata (O.F.Müller, 1776) & - & - & 12,5 \\
\hline 52 Simocephalus vetulus (O.F.Müller,1776) & 25,0 & 87,5 & 87,5 \\
\hline$S$ видів гіллястовусих ракоподібних & 14 & 18 & 21 \\
\hline \multicolumn{4}{|l|}{ Клас Copepoda } \\
\hline 53 Acanthocyclops americanus (Marsh, 1893) & 25,0 & 12,5 & - \\
\hline 54 Cyclops vicinus Ulianine, 1875 & - & - & 12,5 \\
\hline 55 Cryptocyclops bicolor (Sars, 1863) & 37,5 & 50,0 & - \\
\hline 56 Ectocyclops phaleratus (Koch, 1838) & - & 12,5 & - \\
\hline 57 Eucyclops denticulatus (Graeter, 1903) & - & 62,5 & 50,0 \\
\hline 58 Eu. macrurus (Sars, 1863) & - & 12,5 & - \\
\hline 59 Eu. serrulatus (Fischer, 1851) & 100,0 & 75,0 & 87,5 \\
\hline 60 Macrocyclops albidus (Jurine, 1820) & 12,5 & 75,0 & 75,0 \\
\hline 61 M. fuscus (Jurine, 1820) & - & 37,5 & 12,5 \\
\hline 62 Megacyclops gigas (Claus, 1857) & 12,5 & - & - \\
\hline 63 M. viridis (Jurine, 1820) & 87,5 & 25,0 & 37,5 \\
\hline 64 Mesocyclops leuckarti (Claus, 1857) & 37,5 & 87,5 & 50,0 \\
\hline 65 Microcyclops varicans (Sars, 1863 ) & - & 12,5 & 25,0 \\
\hline 66 Thermocyclops crassus (Fischer, 1853) & - & 50,0 & 37,5 \\
\hline 67 Th. dybowskii (Lande, 1890) & _- & 12,5 & - \\
\hline 68 Th. oithonoides (Sars, 1863) & 12,5 & - & 50,0 \\
\hline 69 Eurytemora velox (Lilljeborg, 1853) & 12,5 & - & - \\
\hline$S$ видів веслоногих ракоподібких & 9 & 13 & 10 \\
\hline$S$ видів усіх груп зоопланктону & 33 & 41 & 37 \\
\hline
\end{tabular}

Примітки: Р - частота трапляння виду, або відсоток станцій, у межах яких зареєстровано даний вид, від загальної кількості обстежених станцій (Arsan et al., 2006).

Серед моногононтних коловерток відмічені представники 2 рядів, 8 родин і 12 родів (табл. 2). Високу представленість мали коловертки родин Euchlanidae (5 видів), Brachionidae (6 видів) i Lecanidae (3 види). Гіллястовусі ракоподібні належать до 5 родин i 20 родів, серед яких переважають представники родини Chydoridae (17 видів). Веслоногі ракоподібні включають 2 ряди, 2 родини та 11 родів, серед яких до родини Cусlopidae належить 16 із 17 видів копепод.

Навесні видове багатство зоопланктону річки Удай склало 33 види, серед яких коловерток нараховано 10 (30,3\%) видів, гіллястовусих - 14 (42,4\%) і веслоногих ракоподібних - 9 (27,3\%). У зарослому біотопі зоопланктон представлений 24 видами: коловерток - 5 (20,8\%), гіллястовусих - $12(50,0 \%)$ і веслоногих -7 $(29,2 \%)$. На чистоводді відмічено також 24 види зоопланктерів, серед яких коловерток - 8 (33,3\%) видів, гіллястовусих - 10 (41,7\%) i веслоногих - $6(25,0 \%)$. Влітку зоопланктон мав більше видове багатство (41 вид): коловертки - $10(24,3 \%)$, гіллястовусі - 18 $(44,0 \%)$ і веслоногі - 13 (31,7\%). У межах зарослого біотопу зоопланктон склав 36 видів, з яких коловерток - 9 (25,0\%), гіллястовусих - 14 (38,9\%) і веслоногих ракоподібних - 13 (36,1\%). На чистоводді нараховано 28 видів зоопланктону: коловертки - 8 (28,6\%), гіллястовусі - 11 (39,3\%), веслоногі - 9 (32,1\%). Восени зареєстровано 37 видів: коловерток - 6 (16,2\%), гіллястовусих 21 (56,8\%), веслоногих - 10 (27,0\%). У зарослому біотопі виявлено 31 вид зоопланктону. Тут коловертки склали 3 (9,6\%) види, гіллястовусі - 18 (58,1\%), веслоногі - $10(32,3 \%)$, тоді як у незарослому біотопі - 25 видів: коловертки - 5 (20,0\%), гіллястовусі - $13(52,0 \%)$ та веслоногі - 7 (28,0\%). За фауністичним спектром протягом трьох сезонів переважали представники кладоцерного комплексу. Схожість видового складу зоопланктону за індексом Жаккара характеризується невисокою подібністю під час порівняння весняних і літніх $(\mathrm{J}=25,4)$, весняних і осінніх $(\mathrm{J}=34,5)$ та літніх і осінніх $(\mathrm{J}=34,6)$ угруповань.

\section{Таблиця 2}

Таксономічний склад зоопланктону річки Удай у межах НПП «Пирятинський»

\begin{tabular}{|c|c|c|c|}
\hline Класи & Ряди & Родини & Роди (кількість видів) \\
\hline \multirow{8}{*}{ Eurotatoria } & \multirow{6}{*}{ Ploima } & Asplanchnidae & Asplanchna (1) \\
\hline & & Lecanidae & Lecane (3) \\
\hline & & Euchlanidae & $\begin{array}{l}\text { Dipleuchlanis (1), } \\
\text { Euchlanis (3), } \\
\text { Beauchampiella (1) }\end{array}$ \\
\hline & & Brachionidae & $\begin{array}{l}\text { Brachionus (4), } \\
\text { Notholca (1), } \\
\text { Platyias (1) }\end{array}$ \\
\hline & & Trichotriidae & Trichotria (1) \\
\hline & & Mytilinidae & Mytilina (1) \\
\hline & \multirow{2}{*}{ Flosculariaceae } & Testudinellidae & Testudinalla (1) \\
\hline & & Conochilidae & Conochilus (1) \\
\hline \multirow{5}{*}{ Branchiopoda } & \multirow{5}{*}{ Cladocera } & Sididae & Diaphanosoma (1) \\
\hline & & Daphniidae & $\begin{array}{l}\text { Daphnia (2), } \\
\text { Simocephalus (1), } \\
\text { Ceriodaphnia (6), } \\
\text { Scapholeberis (2) }\end{array}$ \\
\hline & & Macrothricidae & Ilyocryptus (2), Bunops (1) \\
\hline & & Chydoridae & $\begin{array}{l}\text { Acroperus (1), } \\
\text { Graptoleberis (1), } \\
\text { Chydorus (3), } \\
\text { Eurycercus (1), } \\
\text { Alona (2), } \\
\text { Alonella (2), } \\
\text { Alonopsis (1), } \\
\text { Oxyurella (1), } \\
\text { Picripleuroxus (2), } \\
\text { Camptocercus (1), } \\
\text { Pleuroxus (1), } \\
\text { Disparalona (1) }\end{array}$ \\
\hline & & Bosminidae & Bosmina (1) \\
\hline & Calanoida & Temoridae & Eurytemora (1) \\
\hline Copepoda & Cyclopoida & Cyclopidae & $\begin{array}{l}\text { Macrocyclops (2), } \\
\text { Eucyclops (3), } \\
\text { Ectocyclops (1), } \\
\text { Cyclops (1), } \\
\text { Acanthocyclops (1), } \\
\text { Cryptocyclops (1), } \\
\text { Megacyclops (2), } \\
\text { Mesocyclops (1), } \\
\text { Microcyclops (1), } \\
\text { Thermocyclops (3) }\end{array}$ \\
\hline
\end{tabular}

Зоопланктон характеризувався значним різноманіттям, у його складі відмічено представників трьох екологічних груп: пелагічної, придонної та фітофільної. Навесні переважали пелагічна (12 видів - 36,3\%) та фітофільна $(15-45,6 \%)$ групи над придонною $(6-18,1 \%)$. Пелагічна група переважала серед коловерток - 5 $(50,0 \%)$ із 10 видів, фітофільна серед гіллястовусих $-8(57,2 \%)$ iз 14 видів (рис. 2). Влітку серед угруповань зоопланктону переважала фітофільна група - 17 видів або 41,4\% від загальної кількості видів. Значну частку склала фітофільна група серед коловерток $70,0 \%$ або 7 видів із 10 , пелагічна у кладоцер - $38,9 \%$ або 7 видів із 18 , тоді як придонна у веслоногих - 38,4\%, або 5 видів із 13 . Восени фітофільна група також склала значну частку $-48,7 \%$ (18 видів із загальних 37). Коловертки та кладоцери переважали серед фітофільної групи, тоді як копеподи - серед пелагічної. 
Представників різних груп зоопланктону відносять до трьох трофічних груп: мирні, хижі та всеїдні. Протягом різних сезонів переважали представники мирної групи. Навесні вони нараховували 23 (69,7\%) види із 33, хижі - 6 (18,2\%), всеїдні - 4 (12,1\%). Влітку трофічний спектр майже не відрізнявся від весняного. Мирна група представлена 27 (65,8\%) видами із загальних 41, хижі та всеїдні мали однакову кількість видів: 7 (17,1\%) і 7
(17,1\%). Восени всеїдні налічували 3 (8,0\%) види із 37, хижі - 7 $(19,0 \%)$, а мирні - 27 (73,0\%). Коловертки протягом весни та літа представлені мирною групою та одним всеїдним видом (Asplanchna priodonta), тоді як восени лише мирними представниками. Гіллястовусі ракоподібні в дослідний період представлені винятково видами мирної групи, а веслоногі ракоподібні - всеїдними та хижими представниками (рис. 3).

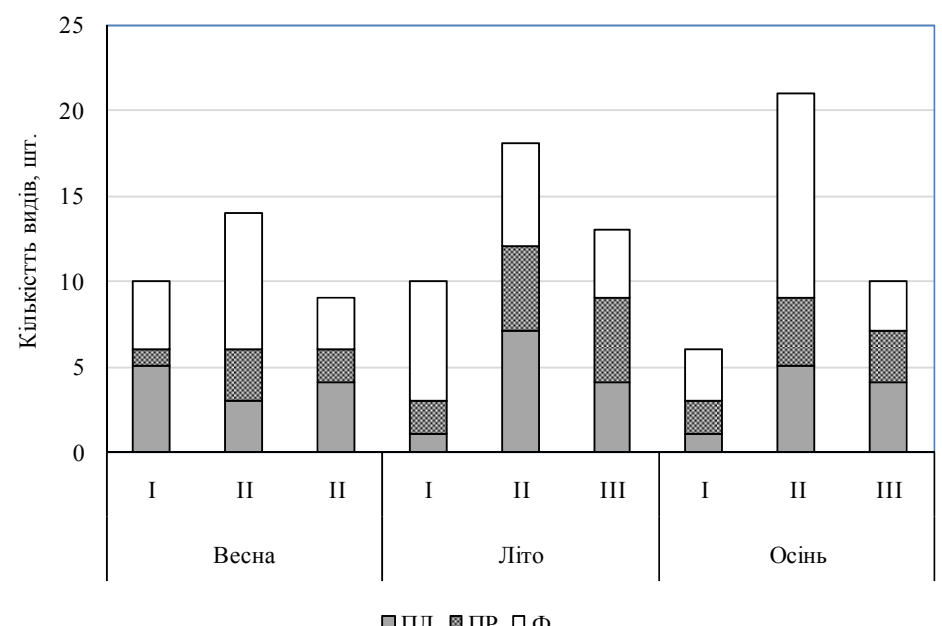

Рис. 2. Сезонні зміни екологічного спектра угруповань зоопланктону р. Удай у межах НПП «Пирятинський»: I - коловертки, II - гіллястовусі ракоподібні, III - веслоногі ракоподібні; ПЛ - пелагічні види, ПР - придонні, Ф - фітофільні

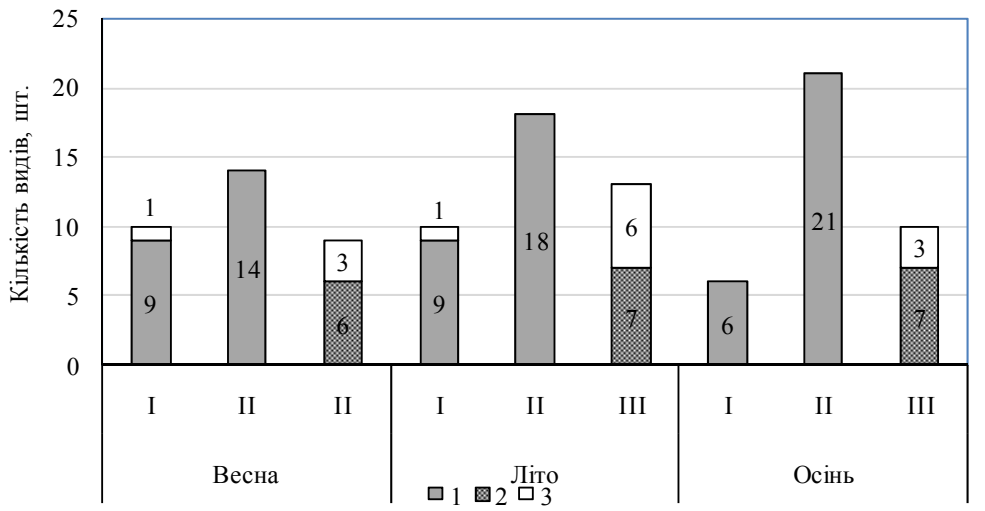

Рис. 3. Сезонні зміни трофічного спектра угруповань зоопланктону р. Удай у межах НПП «Пирятинський»: I - коловертки, II - гіллястовусі ракоподібні, III - веслоногі ракоподібні; 1 - мирна група, 2 - хижі, 3 - всеїдні

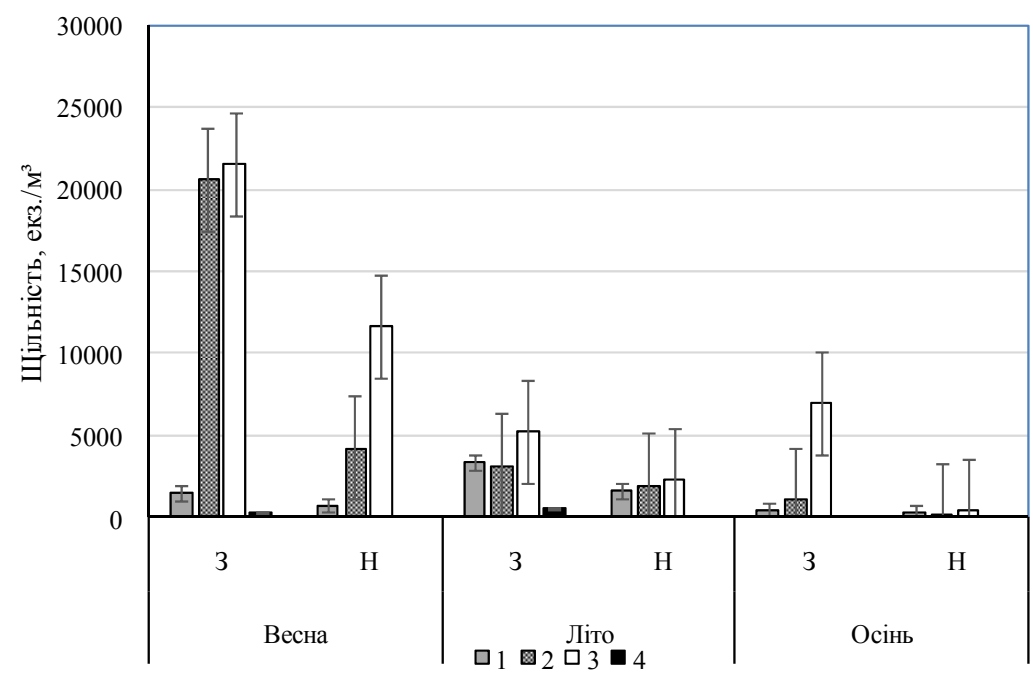

Рис. 4. Сезонні зміни щільності угруповань зоопланктону р. Удай у межах НПП «Пирятинський»: 3 - зарослий біотоп, Н - незарослий біотоп; 1 - коловертки, 2 - гіллястовусі ракоподібні, 3 - веслоногі ракоподібні, 4 - черепашкові ракоподібні 
Навесні показники щільності та біомаси по річці Удай «низькі» - $30389 \pm 19290$ екз./ $\mathrm{M}^{3}$ і $0,61 \pm 0,55 \mathrm{r} / \mathrm{m}^{3}$. У межах зарослого біотопу ці показники також низькі: $44030 \pm 53381$ екз. $/ \mathrm{M}^{3}$ і 1,00 $1,32 \Gamma / \mathrm{M}^{3}$. За щільністю переважають представники гіллястовусих $\left(20625 \pm 32792\right.$ екз./ $\left.\mathrm{m}^{3}\right)$ і веслоногих ракоподібних $(21548 \pm$ 18648 екз./ $\left.\mathrm{M}^{3}\right)$, значно їм поступаються коловертки (1 $535 \pm 1592$ екз./ ${ }^{3}$, рис. 4). Тоді як за біомасою переважають веслоногі $(0,71 \pm$ $\left.0,88 \Gamma / \mathrm{m}^{3}\right)$, а поступаються їм гіллястовусі $\left(0,25 \pm 0,38 \Gamma / \mathrm{m}^{3}\right)$ та коловертки $\left(0,008 \pm 0,016 \mathrm{r} / \mathrm{m}^{3}\right)$. На чистоводді відповідні показники склали $16748 \pm 15665$ екз./ $\mathrm{M}^{3}$ і 0,22 $\pm 0,18$ г/ $\mathrm{M}^{3}$. За щільністю та біомасою переважали веслоногі ракоподібні (11674 \pm 10005 екз. $\mathrm{M}^{3}$ i $0,16 \pm 0,12 \Gamma^{\prime} \mathrm{M}^{3}$, рис. 4,5$)$. Дуже низькі показники у коловерток $\left(771 \pm 927\right.$ екз./ $\mathrm{M}^{3}$ і $\left.0,001 \pm 0,001 \Gamma / \mathrm{M}^{3}\right)$ і гіллястовусих (4 $266 \pm 4672$ екз. $/ \mathrm{m}^{3}$ і $\left.0,05 \pm 0,05 \Gamma / \mathrm{M}^{3}\right)$. Черепашкові ракоподібні мали незначну щільність та біомасу як у зарослому (323 \pm 350 екз. $/ \mathrm{M}^{3}$ i $\left.0,03 \pm 0,03 \mathrm{r} / \mathrm{M}^{3}\right)$ біотопі, так і на чистоводді $(37 \pm 60$ екз./ $\mathrm{M}^{3}$ i $\left.0,004 \pm 0,006 \Gamma / \mathrm{M}^{3}\right)$.

Влітку, порівняно з весною, відповідні показники нижчі:

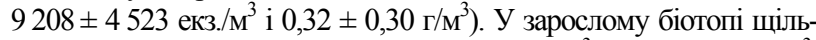
ність і біомаса «низькі»: $12408 \pm 8033$ екз. $/ \mathrm{M}^{3}$ і $0,53 \pm 0,44 \mathrm{r} / \mathrm{m}^{3}$. Для незарослого ці показники «дуже низькі» та «низькі»: $6010 \pm$ 6324 екз./ $\mathrm{M}^{3}$ i $0,10 \pm 0,12 \Gamma / \mathrm{M}^{3}$. У заростях різних формацій вищих водних рослин і на чистоводді за щільністю домінантна група веслоногі ракоподібні (5 $278 \pm 3863$ екз./ м $^{3}$ і $2320 \pm 2356$ екз./ $\left.\mathrm{m}^{3}\right)$, не значно їх поступаються гіллястовусі (3 $198 \pm 2083$ і $2028 \pm$
3127 екз./ M $\left.^{3}\right)$ і коловертки (3 $353 \pm 1562$ і $1643 \pm 794$ екз./ м $\left.^{3}\right)$. Біомаса для обох біотопів дуже низька, домінантною групою виступають гіллястовусі - 0,25 $\pm 0,22$ і $0,06 \pm 0,07 \Gamma / \mathrm{m}^{3}$, значно їм поступаються коловертки $\left(0,005 \pm 0,006\right.$ i $0,003 \pm 0,003$ г/ $\left.\mathrm{M}^{3}\right)$ і веслоногі $\left(0,22 \pm 0,17\right.$ i $0,04 \pm 0,04$ г/M $\left.{ }^{3}\right)$. Для літніх угруповань зоопланктону в межах зарослого $\left(580 \pm 524\right.$ екз./ $\mathrm{M}^{3}$ i $\left.0,058 \pm 0,052 \mathrm{r} / \mathrm{M}^{3}\right)$ i незарослого $\left(20 \pm 47\right.$ екз. $/ \mathrm{M}^{3}$ і $\left.0,002 \pm 0,004 \mathrm{r} / \mathrm{M}^{3}\right)$ біотопів відмічені черепашкові ракоподібні (рис. 4, 5).

Восени щільність та біомаса порівняно 3 попередніми двома сезонами дуже низькі: $4814 \pm 5335$ екз. $/ \mathrm{m}^{3} \mathrm{i}$ 0,147 $\pm 0,172$ г/м $\mathrm{m}^{3}$. Для зарослого біотопу ці показники «дуже низькі» та «низькі» (8588 \pm 12495 екз. $/ \mathrm{M}^{3}$ і $0,27 \pm 0,25$ г/м $\left.{ }^{3}\right)$, тоді як для чистоводдя - «дуже низькі» $\left(1042 \pm 1363\right.$ екз. $/ \mathrm{M}^{3}$ і 0,025 $\left.\pm 0,027 \Gamma / \mathrm{M}^{3}\right)$. За щільністю та біомасою в межах обох біотопів переважали веслоногі ракоподібні (рис. 4, 5). У зарослому біотопі ці показники склали $6958 \pm$ 11082 екз. $/ \mathrm{m}^{3}$ i $0,16 \pm 0,14 \mathrm{\Gamma} / \mathrm{m}^{3}$, а на чистоводді $-454 \pm 345$ екз. $/ \mathrm{m}^{3} \mathrm{i}$ $0,013 \pm 0,007 \mathrm{r} / \mathrm{M}^{3}$. Дуже низька щільність та біомаса у коловерток

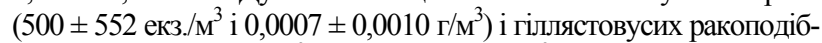

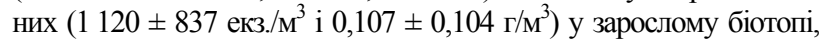
тоді як на чистоводді ці показники ще нижчі: коловертки $-363 \pm$ 734 екз. $/ \mathrm{M}^{3}$ і $0,0004 \pm 0,0007 \mathrm{\Gamma} / \mathrm{m}^{3}$, гіллястовусі $-214 \pm 255$ екз. $/ \mathrm{M}^{3}$ i $0,011 \pm 0,016 \Gamma / \mathrm{m}^{3}$. Черепашкові ракоподібні характеризувались дуже низькою щільністю та біомасою як у зарослому біотопі $(10 \pm$ 24 екз./ $\mathrm{m}^{3}$ i $\left.0,001 \pm 0,002 \Gamma / \mathrm{M}^{3}\right)$, так і на чистоводді $\left(11 \pm 28\right.$ екз./ $\mathrm{m}^{3} \mathrm{i}$ $\left.0,001 \pm 0,002 \Gamma / \mathrm{M}^{3}\right)$.

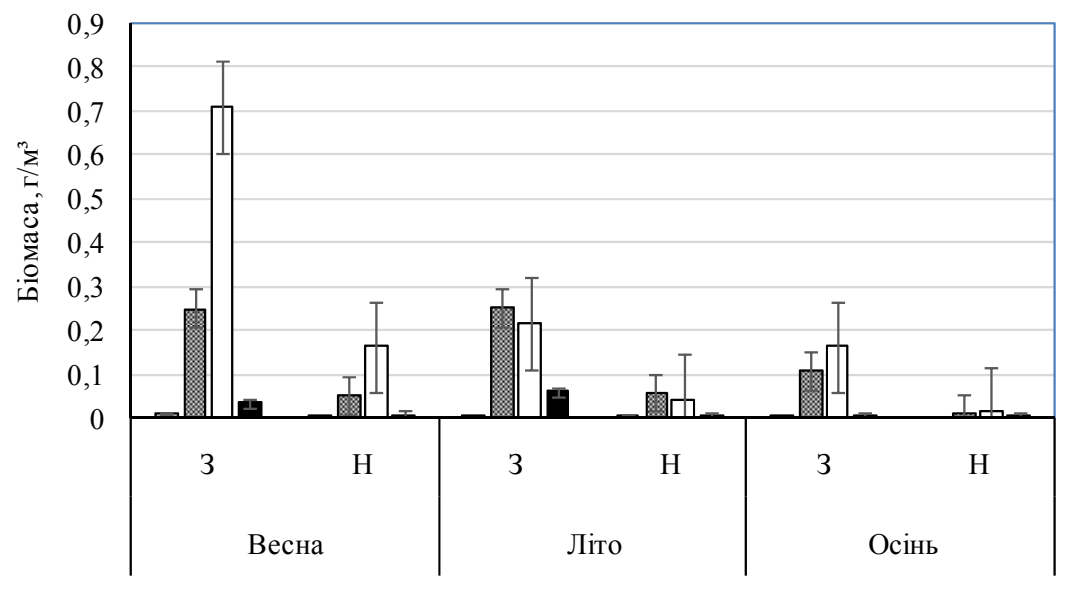

$\square 1$ 圆 2 प $\mathbf{\square}_{4}$

Рис. 5. Сезонні зміни біомаси угруповань зоопланктону р. Удай у межах НПП «Пирятинський»: 3 - зарослий біотоп,

H - незарослий біотоп; 1 - коловертки, 2 - гіллястовусі ракоподібні, 3 - веслоногі ракоподібні, 4 - черепашкові ракоподібні

\section{Обговорення}

Аналіз отриманих даних свідчить, що видове багатство зоопланктону річки Удай мало відрізняється від багатьох малих річок Європи (Illyová et al., 2008; Napiórkowski and Napiórkowska, 2013). Наприклад, для річки Драва, що на Північному Заході Польщі, зареєстровано 118 видів зоопланктону, з яких коловертки склали 87 видів, кладоцери - 21, копеподи - 10 (Czerniawski and PileckaRapacz, 2011). Порівнявши отримані дані 3 попередніми дослідженнями (Trokhymets et al., 2011; Burian and Trokhymets, 2016), доходимо висновку, що відбулася зміна домінантної групи зоопланктону з коловерток на гіллястовусих ракоподібних. Зазвичай домінування коловерток пов'язують зі слабким розвитком макрофітів та низькою температурою.

Щодо видового багатства зоопланктону протягом різних сезонів, влітку відмічено найвищу кількість видів (41), порівняно з весняним (33) та осіннім (37). Такі зміни характерні для цього сезону, тому що саме в цей період масово розвиваються макрофіти, чому сприяє температурний режим. У результаті формуються оптимальні умови для існування гідробіонтів, тоді як для весняного та осіннього сезонів характерні низькі температури, короткотривалість дня та сонячної радіації, внаслідок чого знижується продук- ція фітопланктону, що викликає відповідне зниження біомаси зоопланктону. Навесні та восени зареєстровані холодолюбиві коловертки та копеподи Brachionus urceolaris, Notholca acuminata, Cyclops vicinus. Порівняно з попередніми даними дослідження річки Удай, прослідковується тенденція зниження видового багатства зоопланктону у 2016 році. Протягом літнього періоду у 2010 році зареєстровано 46 видів зоопланктону, у 2015 - 58 (Trokhymets et al., 2011; Burian and Trokhymets, 2016).

Фауністичний спектр угруповань зоопланктону характеризувався переважанням протягом року представників кладоцерного комплексу. Навесні кладоцери склали 42,4\%, влітку - 44,0\%, а восени $-56,8 \%$. Порівняно $з$ літніми дослідженнями 2010, 2015 років прослідковується зміна домінантного комплексу з ротаторнокладоцерного до кладоцерного (Trokhymets et al., 2011; Burian and Trokhymets, 2016). Зазвичай це пов'язують зі сприятливими умовами для розвитку фільтраторів, з яких значну частину складають гіллястовусі ракоподібні.

Аналіз сезонних змін екологічного спектра угруповань зоопланктону виявив три основні групи: пелагічну, фітофільну та придонну. 3 них навесні значну частку склали пелагічна (36,3\%) i фітофільна групи $(45,6 \%)$, а влітку $(41,4 \%)$ та восени $(48,7 \%)-$ фітофільна. Переважання фітофільної групи протягом літнього та 
осіннього сезонів зумовлене більш розвиненим і складним біотопічним багатством прибережної зони річки. Така ж тенденція прослідковується для минулорічних досліджень (Burian and Trokhymets, 2016).

Класичним виявився для таких водойм як річка Удай трофічний спектр зоопланктону, для якого виявлено представників мирної, всеїдної та хижої груп. Проаналізувавши отримані дані різних сезонів, виявили що тенденція представленості різних груп не змінювалась. Найбільший відсоток склала мирна группа: навесні $69,7 \%$, влітку - 65,8\% та восени - 73,0\%. Домінування цієї групи пояснюється переважанням гіллястовусих ракоподібних протягом року, які належать лише до цієї групи.

Щільність та біомаса зоопланктону річки Удай протягом року та в межах різних біотопів «дуже низька» та «низька», що співвідноситься 3 низькою видовою представленістю. Низькі кількісні показники - норма для стабільних водойм. У межах усіх сезонів та біотопів річки переважали представники гіллястовусих і веслоногих ракоподібних (Arsan et al., 2006). Домінування цих груп характеризується високою індивідуальною масою та значною кількістю личинкових стадій веслоногих ракоподібних.

\section{Висновки}

Протягом сезонних досліджень 2016 року угруповань зоопланктону річки Удай у межах НПП «Пирятинський» зареєстровано 69 видів: коловерток - 19 (27,5\%) видів, гіллястовусих ракоподібних - 33 (47,9\%), веслоногих - 17 (24,6\%). Вперше для Полтавської області визначено три види моногононтних коловерток: Beauchampiella eudactylota (Gosse, 1886), Dipleuchlanis propatula (Gosse, 1886), Mytilina acanthophora Hauer, 1938. Протягом весни зібрано 33 види зоопланктону: коловертки - 10 видів, гіллястовусі 14, веслоногі - 9. Влітку зареєстровано 41 вид, 3 яких коловерток 10 , гіллястовусих -18 , гіллястовусих -13 . Восени виявлено 37 видів: 6 видів коловерток, гіллястовусих -21 , веслоногих -10 . Виявлено невисоку видову схожість (за індексом Жаккара) зоопланктону в різні сезони: $\mathbf{J}=25,4-34,6$. Протягом весни, літа та осені переважали представники гіллястовусих ракоподібних. Навесні переважали пелагічна (36,3\%) та фітофільна (45,6\%) групи, а влітку $(41,4 \%)$ та восени $(48,7 \%)$ - фітофільна. За типом живлення протягом дослідних сезонів переважали представники мирної групи, які навесні склали 69,7\%, влітку $-65,8 \%$, восени $-73,0 \%$. Кількісні показники зоопланктону річки Удай навесні (30389 \pm 19290 екз. $/ \mathrm{m}^{3}$ і $\left.0,61 \pm 0,55 \Gamma / \mathrm{m}^{3}\right)$ і влітку $\left(9208 \pm 4523\right.$ екз./ $\mathrm{m}^{3} \mathrm{i}$ $\left.0,32 \pm 0,30 \Gamma / \mathrm{M}^{3}\right)-$ «низькі», восени $\left(4814 \pm 5335\right.$ екз./ $\mathrm{M}^{3}$ і $0,15 \pm$ $\left.0,17 \Gamma / \mathrm{M}^{3}\right)$ - «дуже низькі».

\section{References}

Arsan, O. M., ed. (2006). Metody hidrobiolohichnykh doslidzhen' poverkhnevykh vod [Methods of hydroecological investigations of surface water]. Logos, Kyiv (in Ukrainian).

Baranyi, C., Hein, T., Holarek, C., Keckeis, F., \& Schiemer, F. (2002). Zooplankton biomass and community structure in a Danube River floodplain system. Freshwater Biology, 47(3), 473-482.

Berezina, N. A. (1989). Praktikum po gidrobiologii [Workshop on Hydrobiology]. Agropromizdat, Moscow (in Russian).

Boruckij, E. V., Stepanova, L. A., \& Kos, S. (1991). Opredelitel' Calanoida presnyh vod SSSR [Determinant of Calanoida of fresh waters of USSR]. Nauka, Leningrad (in Russian).

Burdis, R. M., \& Hoxmeier, R. J. H. (2011). Seasonal zooplankton dynamics in main channel and backwater habitats of the Upper Mississippi River. Hydrobiologia, 667(1), 69-87.

Burian, Z., \& Trokhymets, V. (2016). Structural and faunistic organization of the Uday river's littoral zooplankton in the National Nature Park "Pyriatynskiy". Visnyk of Taras Shevchenko National University of Kyiv, 72, 56-59.

Czerniawski, R., \& Domagała, J. (2010). Similarities in zooplankton community between River Drawa and its two tributaries (Polish part of River Oder). Hydrobiologia, 638(1), 137-149.

Czerniawski, R., Pilecka-Rapacz, M., \& Domagała, J. (2013). Zooplankton communities of inter-connected sections of lower River Oder (NW Poland). Central European Journal of Biology, 8(1), 18-29.
Czerniawski, R., \& Pilecka-Rapacz, M. (2011). Summer zooplankton in small rivers in relation to selected conditions. Central European Journal of Biology, 4, 659-674.

Fefilova, E. B. (2011). The state of a river in pechora basin after an oil spill: Assessment of changes in zooplankton community. Water Resources, 38(5), 593-605.

Illyová, M., Bukvayová, K., \& Némethová, D. (2008). Zooplankton in a Danube River Arm near Rusovce (Slovakia). Biologia, 63(4), 566-573.

Kononova, O. N. (2009). Zooplankton in the Vychegda River. Inland Water Biology, 2(2), 149-156.

Manujlova, E. F. (1964). Vetvistousye rachki (Cladocera) fauny SSSR [Cladocerans (Cladocera) fauna of the USSR]. Nauka, Moscow-Leningrad (in Russian).

Martin, J. W., \& Davis, G. E. (2001). An updated classification of the recent Crustacea. Natural History Museum of Los Angeles Country, Los Angeles.

Monchenko, V. I. (2003). Vol'nozhivushhie ciklopovidnye kopepody Ponto-Kaspijs'kogo bassejna [Free-living cyclopoid copepods of Ponto-Kaspian basin]. Naukova Dumka, Kyiv (in Russian).

Napiórkowski, P., \& Napiórkowska, T. (2013). The diversity and longitudinal changes of zooplankton in the lower course of a large, regulated European river (the lower Vistula River, Poland). Biologia, 68(6), 1163-1171.

Ning, N. S. P., Gawne, B., \& Cook, R. A. (2013). Zooplankton dynamics in response to the transition from drought to flooding in four Murray-Darling Basin rivers affected by differing levels of flow regulation. Hydrobiologia, 702(1), 45-62.

Ovander, E., Iakovenko, N., Trokhymets, V., Gromova, Y., Pashkova, O., \& Guleikova, L. (2011). Anotovanyy spysok monohonontnykh koloertok ryadu Ploima (Rotifera: Eurotatoria, Monogononta, Ploima) fauny Ukrayiny. Povidomlennya I [Annotated checklist of Monogonont Rotifers belonging to order Ploima (Rotifera: Eurotatoria, Monogononta, Ploima) of Ukraine. Part I]. Fisheries Science of Ukraine, 16, 59-69 (in Ukrainian).

Ovander, E., Iakovenko, N., Trokhymets, V., Gromova, Y., Pashkova, O., \& Guleikova, L. (2011). Anotovanyy spysok monohonontnykh koloertok ryadu Ploima (Rotifera: Eurotatoria, Monogononta, Ploima) fauny Ukrayiny. Povidomlennya II [Annotated checklist of Monogonont Rotifers belonging to order Ploima (Rotifera: Eurotatoria, Monogononta, Ploima) of Ukraine. Part II]. Fisheries Science of Ukraine, 17, 46-54 (in Ukrainian).

Ovander, E., Iakovenko, N., Trokhymets, V., Gromova, Y., Pashkova, O., \& Guleikova, L. (2011). Anotovanyy spysok monohonontnykh koloertok nadryadu Gnesiotrocha (Rotifera: Eurotatoria, Monogononta, Gnesiotrocha) fauny Ukrayiny. Povidomlennya III [Annotated checklist of Monogonont Rotifers belonging to the superorder Gnesiotrocha (Rotifera: Eurotatoria, Monogononta, Gnesiotrocha) of Ukraine. Part III]. Fisheries Science of Ukraine, 18, 41-51 (in Ukrainian).

Pashkova, O. V. (2013). Zooplankton as indicator of organic and toxic pollution and ecological state of aquatic ecosystems (a review). Hydrobiological Journal, 49(2), 3-20.

Pesenko, J. A. (1982). Principy i metody kolichestvennogo analiza v faunisticheskih issledovanijah [Principles and methods of quantitative analysis in the faunal studies]. Nauka, Moscow (in Russian).

Podshivalina, V. N. (2012). Zooplankton of the Bol'shoi Tsivil River (Middle Volga Region) under a changing hydrological mode and an increasing anthropogenic load. Biology Bulletin, 39(10), 823-828.

Segers, H. (2008). Global diversity of rotifers (Rotifera) in freshwater. Hydrobiologia, 595, 49-59.

Segers, H. (2007). Annotated checklist of the rotifers (phylum Rotifera), with notes on nomenclature, taxonomy and distribution. Magnolia Press, New Zealand.

Smyrnova, V. G. (2013). Transformacija richok ta richkovyh rusel (na prykladi richkovyh vodnyh ob'jektiv Poltavs'koi' oblasti) [Transformation of the rivers and river channels (for example of the river water objects of Poltava region)]. Hydrology, Hydrochemistry and Hydroecology, 28, 109-116 (in Ukrainian).

Trokhymets, V. N., Sydorenko, M. V., \& Podobaylo, A. V. (2012). The Uday river's littoral zooplankton in the region of the national nature park «Pyriatynskiy». Visnyk of Dnipropetrovsk University. Biology, Ecology, 20(1), 131-138.

Uttah, E. C., Uttah, C., Akpa, P. A, Ikpeme, E. M., Ogbeche, J., Usip, L., \& Asor, J. (2010). Bio-survey of plankton as indicators of water quality for recreational activities in Calabar River, Nigeria. Journal of Applied Sciences and Environmental Management, 12(2), 35-42.

Yatsyk, A. V., ed., (1991). Mali richky Ukrayiny [Small rivers of Ukraine] Kyiv, Urozhay (in Ukrainian).

Yermolaeva, N. I. (2013). Modern state of zooplankton in Vasyugan River. Contemporary Problems of Ecology, 6(6), 627-633.

Zhadin, V. N. (1960). Metody gidrobiologicheskogo issledovanija [Methods of hydrobiological studies]. Vysshaja Shkola, Moscow (in Russian). 